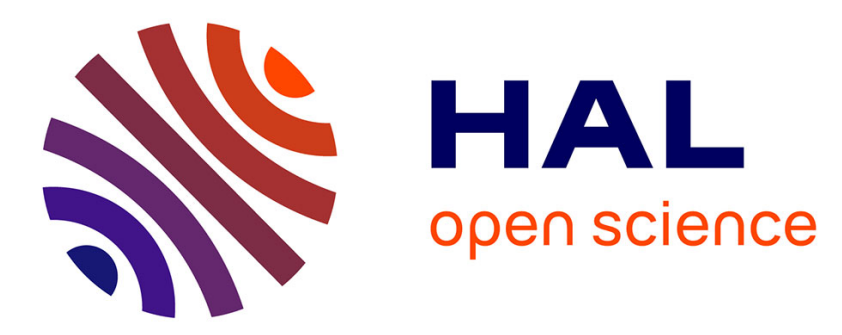

\title{
Long-term effects of topsoil transfer assessed thirty years after rehabilitation of dry alluvial quarries in Southeastern France
}

Julie Chenot, Renaud Jaunatre, Elise Buisson, Thierry Dutoit

\section{- To cite this version:}

Julie Chenot, Renaud Jaunatre, Elise Buisson, Thierry Dutoit. Long-term effects of topsoil transfer assessed thirty years after rehabilitation of dry alluvial quarries in Southeastern France. Ecological Engineering, 2017, 99, pp.1-12. 10.1016/j.ecoleng.2016.11.010 . hal-01681564

\author{
HAL Id: hal-01681564 \\ https://hal.science/hal-01681564
}

Submitted on 4 May 2018

HAL is a multi-disciplinary open access archive for the deposit and dissemination of scientific research documents, whether they are published or not. The documents may come from teaching and research institutions in France or abroad, or from public or private research centers.
L'archive ouverte pluridisciplinaire HAL, est destinée au dépôt et à la diffusion de documents scientifiques de niveau recherche, publiés ou non, émanant des établissements d'enseignement et de recherche français ou étrangers, des laboratoires publics ou privés. 
1 Long-term effects of topsoil transfer assessed thirty years after 2 rehabilitation of dry alluvial quarries in Southeastern France

3

4

5

6

\author{
Julie Chenot $^{1,2}$, Renaud Jaunatre ${ }^{3}$, Elise Buisson ${ }^{1}$, Thierry Dutoit ${ }^{1}$ \\ 1. Institut Méditerranéen de Biodiversité et d'Ecologie (IMBE), Université d'Avignon et \\ des Pays de Vaucluse, UMR CNRS IRD Aix Marseille Université, IUT site Agroparc, \\ BP 61207, 84911 Avignon cedex 09, France \\ chenot.julie@gmail.com,_elise.buisson@univ-avignon.fr, thierry.dutoit@univ- \\ avignon.fr \\ 2. Société des Carrières de la Ménudelle, 13. BP 80011, 13551 Saint-Martin-de-Crau, \\ France \\ chenot.julie@gmail.com \\ 3. Université Grenoble Alpes, Irstea, UR EMGR, 2 rue de la Papeterie-BP 76, F-38402 \\ St-Martin-d'Hères, France \\ renaud.jaunatre@irstea.fr
}

\begin{abstract}
Of the many techniques tested to date to rehabilitate degraded ecosystems, topsoil transfer appears to offer the best results. However, this method is recent, and results achieved in the short term (months to years) may not provide a sound indication of long-term vegetation reestablishment. In the plain of La Crau in southeastern France, many dry alluvial quarries were exploited in the 1970s -1980s and are nearly all now abandoned. Various topsoil transfers were performed when operations ceased, for various rehabilitation purposes (aesthetic, security, agricultural, etc.) and now provide the opportunity to test their efficacy in the 30-year long-term. We used an ecological analysis of plant communities and soil carried out in 2015 to compare the reference ecosystem (the steppe of La Crau, positive control) with un-rehabilitated quarry pits (negative control) and with four different rehabilitation treatments: (1) soil transfer $(40 \mathrm{~cm})$ with no contact with the water table; (2) soil transfer $(40 \mathrm{~cm})$ in contact with the water table; (3) more than $40 \mathrm{~cm}$ of soil transfer and (4) anthropogenic material deposits (spoils) unrelated to the characteristics of the reference soil. Our results show that the treatment most favorable to restoration of the species richness, diversity and composition of the steppe vegetation is transferring soil with fine particles (clay, silt) (treatment 1), at least $40 \mathrm{~cm}$ thick and without contact with groundwater. However, even after thirty years, and the reestablishment of traditional sheep grazing, full restoration of the reference steppe is far from being achieved. The other treatments lead to the emergence of hybrid or novel ecosystems, such as temporary ponds, riparian woodlands or matorrals with new variables and common variables to the historical ecosystem. Additional techniques to enhance the effectiveness of topsoil transfer are discussed.
\end{abstract}

Keywords: alpha diversity, gamma diversity, quarry rehabilitation, Mediterranean ecosystem, soil analyses, steppe plant community. 


\section{Introduction}

The constant acceleration of urbanization and industrialization worldwide, with the ensuing demand for mineral resources, means that newly-created quarries have largely destroyed many natural ecosystems (Wang et al., 2011). Quarrying results in significant visual and ecological impacts (Simón-Torres et al., 2014), not all of which have been identified yet (El-Taher et al., 2016). Quarrying causes drastic alterations. It destroys flora and fauna, thereby reducing biodiversity and disrupting fundamental ecological relationships. Moreover, it extensively damages soil by modifying the original site topography and depleting and altering soil microbial communities (Corbett et al., 1996; Pinto et al., 2001; Milgrom, 2008; Mouflis et al., 2008; Simón-Torres et al., 2014). Other impacts identified at regional level include nuisance to local residents, with dust, noise pollution and ground vibrations when topsoil is dug up with heavy machinery (Mohamed and Mohamed, 2013; Dontala et al., 2015). Quarrying can also cause chemical contamination of groundwater by increasingly hazardous materials (Misra, 2013; Dontala et al., 2015).

Today, many countries have legislation requiring mining and quarrying companies to implement ecological restoration after closure (DITR, 2005; UNEP et al., 2005; European Parliament, 2014). Ecological restoration sensu lato is the process of assisting the recovery of an ecosystem that has been degraded, damaged, or destroyed (SER, Society for Ecological Restoration International, Science \& Policy Working Group, 2004). The goals of restoration sensu stricto include the re-establishment of the pre-existing biotic integrity in terms of species composition and community structure. Many quarries thus implement rehabilitation or reclamation actions of benefit to biodiversity (Damigos and Kaliampakos, 2003; Carrick and Krüger, 2007). Rehabilitation seeks to repair one or more ecosystem attributes, processes, or services. Reclamation, on the other hand, includes land stabilization, public safety guarantees, aesthetic improvement and usually a return of the ecosystem considered useful in the regional context (Society for Ecological Restoration International, Science \& Policy Working Group, 2004).

Numerous experiments conducted worldwide testify to the many quarry rehabilitation techniques in use, in particular for vegetation. For example, shrub species were planted in dolomite rock quarries in China (Wang et al., 2011) or in limestone quarries in Portugal (Oliveira et al., 2011) to rehabilitate areas formerly degraded by an increased bare ground soil surface sensitive to water or wind erosion. This involved adding an improved marl substrate layer on top of the bare rock (Oliveira et al., 2011). Other techniques using substitute substrates with fertilizers, water-holding polymers, geotextiles and mycorrhizal inoculations were used to enhance vegetation growth after marble mining in Spain. However, long-term monitoring is rarely implemented, and those results available are not encouraging (Oliveira et al., 2011). Yet this rather limited effect of rehabilitation contrasts with the sometimes high diversity found in some abandoned quarries (Remacle, 2009; Chapel, 2011; Prach et al., 2013; Pitz et al., 2014). This paradox suggests a need to determine the most beneficial measures for the rehabilitation of singular flora and vegetation in disturbed areas, and for research specifically aimed at those inhabiting quarry habitats (Oliveira et al., 2011; Ballesteros et al., 2014). 
One of the most frequently used techniques is to cover the post-quarrying exposed geological substrate, either with a layer of topsoil removed pre-quarrying and conserved in stockpiles during quarrying (topsoil transfer) (Simón-Torres et al., 2014), or with an artificially created soil (artificial soils) (Frouz et al., 2008; Weber et al., 2015). Topsoil transfer consists in removing the uppermost centimeters of topsoil from a donor site of ecological interest. This topsoil can be the pre-existing soil from the site itself, or can come from another site already programmed for destruction (Bulot et al., 2016). The soil is then re-spread on the sites to be restored (Ghose, 2001; Sheoran et al., 2010). It can consist in a direct topsoil transfer from another site that begins to be exploited. In such case, there is no storage of topsoil and therefore a better chance of rehabilitation successful (Rivera et al., 2014). In other cases, topsoil is stored for the duration of mining exploitation, the quality of soil and seed bank are then altered and this reduces the chances of rehabilitation success (Ghose, 2001; Strohmayer, 1999). Topsoil transfer can be used to save ecological features and their associated ecosystem services from donor sites (Box, 2003). It has been evaluated as the best rehabilitation method to compensate for the many projects necessarily involving destruction to make way for consented or permitted development (Box, 2014). However, success monitoring rarely exceeds the first few years (Koch, 2007; Oliveira et al., 2011; Muller et al., 2013; Bulot et al., 2014; Jaunatre et al., 2014a; Bulot et al., 2016). Most restoration involving soil transfer has been recent and/or has not been examined scientifically (Fowler et al., 2015). The long-term effects (over several decades) of topsoil transfer on target species survival are therefore not known. Moreover, results obtained in the first months or years after implementation do not necessarily provide a good indication of longer-term responses (Cooke and Johnson, 2002; D'Antonio and Meyerson, 2002; Herrick et al., 2006; Oliveira et al., 2011; Gaucherand et al., in press). Studies assessing medium- and long-term results are, therefore, essential for a fuller evaluation of these techniques.

In the plain of La Crau in southeastern France, many dry alluvial quarries were exploited in the 1970s for the creation of the Fos-sur-Mer port zone. These activities resulted in the destruction of nearly 300 hectares of the unique La Crau steppe ecosystem (Buisson and Dutoit, 2006). When quarrying ceased fifteen years later, the companies were not required by law to rehabilitate the environment after mining. Various rehabilitation trials, mainly using different soil transfer techniques, were thus implemented, mainly with aesthetic aims (i.e. creating a flat area like the steppe landscape) or security objectives (i.e. to avoid potholes).

Monitoring the soil and vegetation of these quarry pits today therefore provides the opportunity for 30-year long-term feedback on these techniques (i.e. involving different soil sources, composition, thickness and with or without contact with the groundwater table). Plant communities and soil physico-chemical parameters in rehabilitated pits were compared to a positive control, the steppe, generally considered as the reference ecosystem (Dutoit et al., 2013; Hobbs et al., 2013) and to a negative control without any soil transfer treatment. The soil of this surrounding steppe was the one that existed before it was destroyed by quarrying. To evaluate the biological importance of the newly created habitats, we worked at different spatial scales. We took into account both local (alpha) and regional biodiversity (gamma diversity), as well as the originality of the plant communities in relation to a landscape repository. 


\section{Materials and methods}

\subsection{Study site}

Our study was carried out in the plain of La Crau, located in southeastern Mediterranean France (Bouches-du-Rhône) (Fig. 1A). Characterized by a unique natural habitat, the plain was classified in 1990 as a Special Protection Area under Natura 2000, called Steppe of La Crau, the last remaining French Mediterranean steppe (Buisson and Dutoit, 2006). Its Mediterranean substeppic grassland plant community features the phytosociological association Asphodeletum fistulosii (Molinier and Tallon, 1950) dominated by species such as Brachypodium retusum (Pers.) P. Beauv, Thymus vulgaris L. and Asphodelus ayardii Jahand and Marie. This plant community is unique in terms of species richness, composition and diversity (Cherel, 1988; Badan et al., 1995; Henry, 2009). There are on average 30 to 40 plant species per square meter, $50 \%$ of which are annuals (Römermann et al., 2005). This plant community may result from a regressive or allogenic plant succession of thousands of years under the combined effects of i) the dry and windy Mediterranean climate, ii) specific soil conditions: the $40 \mathrm{~cm}$ deep soil is composed of $50 \%$ siliceous stones and lies on a calcareous conglomerate which cannot be penetrated by plant roots (Molliex et al., 2013) and iii) a recurring disturbance regime constituted by itinerant sheep grazing since the end of the Neolithic period (Badan et al., 1995; Lebaudy, 2004; Henry et al., 2010; Tatin et al., 2013).

Our study site was located in the south of the plain of La Crau $\left(43^{\circ} 31^{\prime} 36.77^{\prime \prime} \mathrm{N}\right.$, $\left.4^{\circ} 53^{\prime} 04.50^{\prime \prime} \mathrm{E}\right)$. Present on the site are 296 ha of open quarries once exploited for road ballast or materials for the construction of docks in the Fos-sur-Mer port zone (Fig. 1). All these quarries were abandoned in the 1980s, as seen from old aerial photographs (1938 - 2015) (Fig. 2). A shallow Haplic Cambisol soil WRB (IUSS Working Group WRB, 2006) $40 \mathrm{~cm}$ deep lying above the geological conglomerate (composed of quartz pebbles in a calcium carbonate matrix forming a limestone 1 to $5 \mathrm{~m}$ thick), hereafter named topsoil, was removed from these quarries and exported, sold or stored. This made way for quarrying the underlying geological substrate (a 10 to $50 \mathrm{~m}$ thick mixture of Quaternary pebbles and sands deposited in a former large alluvial fan during the Riss-Wurm glacial period,(Molliex et al., 2013)) below the conglomerate.

In most quarry pits (44\% of the study site area), no material was replaced after quarrying, leaving exposed the un-disturbed geological material, or the surface of the water table when quarrying went more than nine meters deep (average water table height). We therefore considered this situation a negative control with no attempt at rehabilitating the soil or the vegetation for ecological or other reasons (Table 1). However, in some cases, quarry pits were partly filled with anthropogenic spoil materials combining various proportions of gravels, clays and sands, conglomerate or concrete blocks, etc. (11\% of the study site area). This situation was considered as a rehabilitation treatment, since these new artificial soils provided conditions favorable to new primary plant successions, even though nothing was done to drive these successions towards the plant composition and dynamics of the reference steppe plant community. Contrastingly, at the initiative of certain quarry operators, other quarry pits had stored topsoil re-spread on top of the spoil materials ( $45 \%$ of the study site area) to various depths, including a depth similar to the reference steppe $(40 \mathrm{~cm})$ and a greater depth (more than $40 \mathrm{~cm}$ of topsoil added). 
Differing quarry operating conditions, followed by differing rehabilitation treatments in the eighties, provided us with a great diversity of artificial geomorphological and pedological situations whose impacts on the present vegetation could be compared. We compared this vegetation both to the steppe vegetation (positive control) generally considered as the reference ecosystem in the previous restoration projects realized in this area (Dutoit et al., 2013), and to quarry pits with no rehabilitation treatments (negative control) (Table 1). In total, four situations were identified along a rehabilitation gradient: (1) soil transfer $(40 \mathrm{~cm})$ with no contact with the water table, $(2)$ soil transfer $(40 \mathrm{~cm})$ in contact with the water table, (3) more than $40 \mathrm{~cm}$ of soil transfer and (4) anthropogenic deposits (spoils) (Table 1). These four situations were identified by the use of ancient aerial photographs (Fig. 2), soil profiles and interviews of quarry operators.
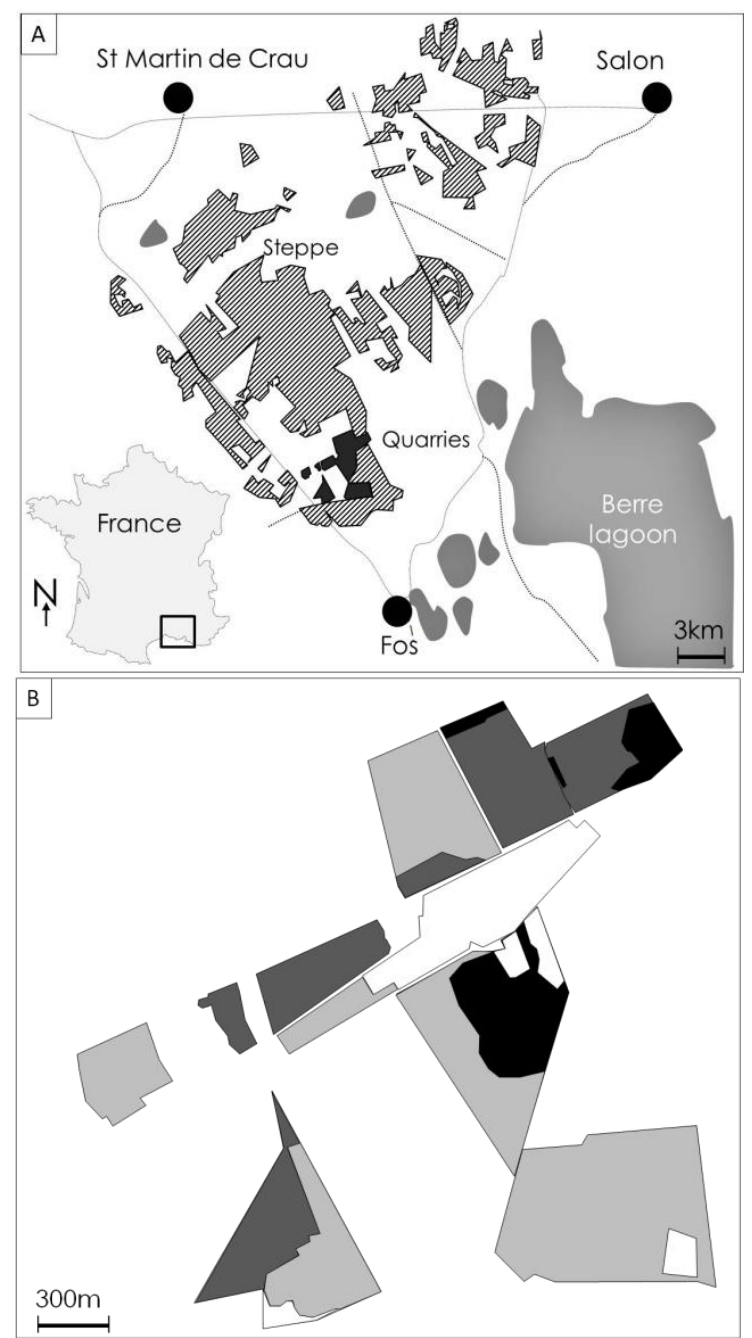

Fig. 1. Location of study site and experimental design. (A) Location of the plain of La Crau area in France and location of the remnant patches of steppe (striped grey) and quarries (black); (B) experimental design of the different rehabilitation treatments realized on the abandoned quarries in the 1980s: $40 \mathrm{~cm}$ soil transfer (dark grey); > $40 \mathrm{~cm}$ soil transfer (black); anthropogenic deposits (white) and no rehabilitation (light grey). 

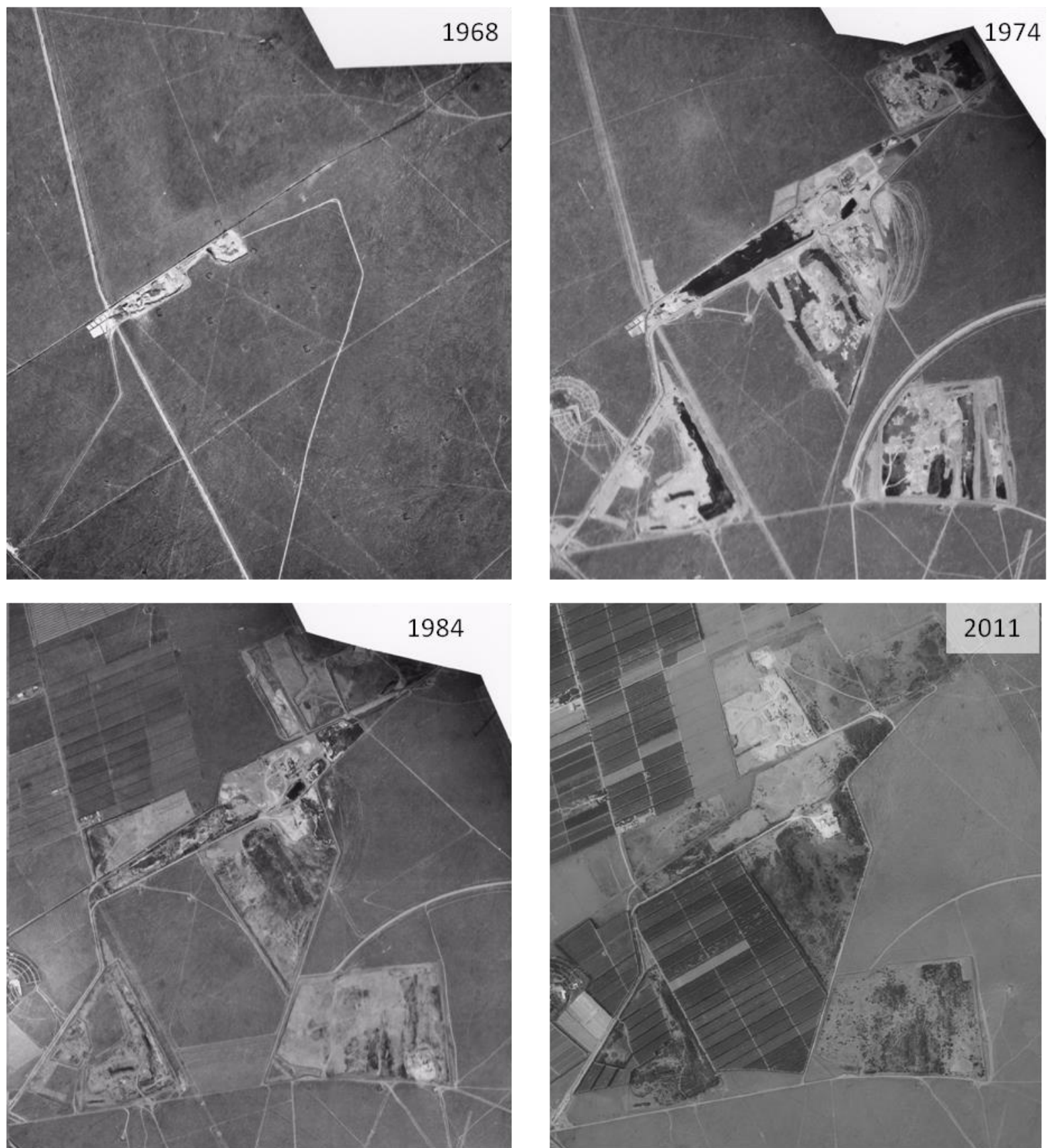

Fig. 2. Quarry expansion in the seventies and eighties visible from old aerial photographs (1968 - 1974 $1984-2011$-IGN). The extension of intensive orchard areas since 1984 can also be observed between the quarries. 
Table 1. Various rehabilitation treatments and controls used in this study and analyses performed on each treatment

\begin{tabular}{|c|c|c|c|}
\hline & Treatments & $\begin{array}{c}\text { Sample number } \\
\text { for soil } \\
\text { analyses }\end{array}$ & $\begin{array}{l}\text { Transect number } \\
\text { for vegetation } \\
\text { sampling }\end{array}$ \\
\hline Positive control & Reference Steppe & 5 & 6 \\
\hline \multirow{3}{*}{$\begin{array}{l}\text { Topsoil } \\
\text { transfer }\end{array}$} & $\begin{array}{l}40 \mathrm{~cm} \text { soil transfer with no contact with the water } \\
\text { table }\end{array}$ & 4 & 4 \\
\hline & $40 \mathrm{~cm}$ soil transfer in contact with the water table & 5 & 3 \\
\hline & $>40 \mathrm{~cm}$ soil transfer & 5 & 3 \\
\hline $\begin{array}{l}\text { Anthropogenic } \\
\text { soil }\end{array}$ & Anthropogenic deposits (spoils) & 5 & 5 \\
\hline Negative control & $\begin{array}{l}\text { No rehabilitation: absence of deposits or soil } \\
\text { spreading in the quarried geological substratum }\end{array}$ & 5 & 4 \\
\hline
\end{tabular}

\subsection{Vegetation analyses}

Vegetation sampling using $4 \mathrm{~m}^{2}$ quadrats was carried out in May 2015. For each of the six treatments, depending on available area, 3 to 6100 -meter transects were replicated, each composed of five pseudo-replicated quadrats (Fig. 1; Table 1). Quadrats were pseudo-replicated on the same site along each transect, so as to reveal any heterogeneity in the spatial distribution of plant communities for the same treatment. The number of replicated transects differed according to type of treatment in the quarries sampled. On each transect, quadrats were spaced more than $10 \mathrm{~m}$ apart, to prevent spatial autocorrelation between quadrats (Buisson et al., 2006). The abundance of each plant species was visually estimated, in percent cover (Gillet, 2000).

\subsection{Soil analyses}

Soil analyses were carried out on twenty-nine $200 \mathrm{~g}$ soil samples taken from abandoned quarries in 2015 (Table 1). Samples were extracted from the first ten centimeters of the upper soil/material layer in February 2015. Each sample was dried and sieved with a $2 \mathrm{~mm}$ mesh sieve. Chemical content (organic C (Allison, 1965), total $\mathrm{N}$ (Bremner, 1996), C:N, CEC Metson (Metson, 1956; Ciesielski et al., 1997), K, $\mathrm{P}_{2} \mathrm{O}_{5}$ (Olsen, 1954), $\mathrm{CaCO}_{3}$, pH (Sparks et al., 1996; Thomas, 1996)) and fine particle sizes ( $<2 \mathrm{~mm}$ ) (percentages of clay: $<0.002 \mathrm{~mm}$; fine silt: $0.002-0.02 \mathrm{~mm}$; coarse silt: $0.2-2$ $\mathrm{mm}$; fine sand: 0.05-0.2 $\mathrm{mm}$; and coarse sand: 0.2-2 mm) (Gee and Bauder, 1986) were measured without decarbonization by the soil analysis laboratory at INRA (Institut National de la Recherche Agronomique) in Arras. 


\section{Results}

\subsection{Effect of topsoil transfer on soil physico-chemical parameters}

The different rehabilitation treatments showed significant differences in soil physico-chemical properties (Table 2, Fig. 3). The PCA ordination based on soil properties significantly discriminated the different treatments. Axis 1 (45.3\% of inertia) separated topsoil (steppe and soil) transfer from the negative control with no spoil deposits or soil spreading. This separation is explained partly by the quantities of clay, which were significantly higher in the steppe and soil transfers. Conversely, in the absence of deposits or soil spreading, the substrate was characterized by significantly higher amounts of coarse sand, higher $\mathrm{C}: \mathrm{N}$ ratios and higher $\mathrm{pH}$.

Axis 2 (25.8\% of inertia) clearly separated the soils of the reference steppe and of the soil transfer treatments from those of the negative control and spoil deposits. The soils 
of topsoil transfer treatments tended to be closer to that of the reference steppe, especially those which were not in contact with the water table.

\section{Table 2}

Soil analyses for each rehabilitation treatment realized in May 2015. The given values are means \pm standard errors. The $\mathrm{F}$ value and $\mathrm{p}$ value are from ANOVA and the $\mathrm{X}^{2}$ value is from Kruskal-Wallis tests on the effects of treatments on each variable. Two values in the same row with a different letter are significantly different according to Tukey post-hoc tests or Mann-Whitney-Wilcoxon tests (Bonferroni, 1936).

\begin{tabular}{|c|c|c|c|c|c|c|c|c|}
\hline & $\begin{array}{c}\text { Statistic } \\
\text { parameter }\end{array}$ & p-value & $\begin{array}{l}\text { Reference } \\
\text { steppe } \\
\text { (Positive } \\
\text { control) }\end{array}$ & $\begin{array}{c}\text { Topsoil } \\
\text { transfer }(40 \\
\text { cm) with no } \\
\text { contact with } \\
\text { the water } \\
\text { table }\end{array}$ & $\begin{array}{c}\text { Topsoil } \\
\text { transfer }(40 \\
\text { cm) in contact } \\
\text { with the water } \\
\text { table }\end{array}$ & $\begin{array}{c}\text { Topsoil } \\
\text { transfer } \\
\text { (More than } \\
40 \mathrm{~cm})\end{array}$ & $\begin{array}{c}\text { Anthropogenic } \\
\text { material } \\
\text { deposits }\end{array}$ & $\begin{array}{c}\text { No rehabilitation } \\
\text { Absence of soil } \\
\text { spreading/material } \\
\text { deposits } \\
\text { (Negative control) }\end{array}$ \\
\hline Clay $\left(\mathrm{g} \mathrm{kg}^{-1}\right)$ & $\begin{array}{c}X^{2}=19.38 \\
D f=6\end{array}$ & $0.004 * *$ & $231.2 \pm 6.6 \mathrm{~b}$ & $199.5 \pm 33.9 \mathrm{~b}$ & $223.4 \pm 4 b$ & $204 \pm 17.5 b$ & $109.8 \pm 28.1 \mathrm{a}$ & $98.8 \pm 8.9 \mathrm{a}$ \\
\hline Fine silt $\left(\mathrm{g} \mathrm{kg}^{-1}\right)$ & $\mathrm{F}_{6,27}=1.7$ & 0.16 & $210.8 \pm 5.5$ & $173.5 \pm 15.3$ & $177.4 \pm 2.7$ & $176.8 \pm 6.5$ & $150.8 \pm 46.3$ & $131.6 \pm 13$ \\
\hline $\begin{array}{l}\text { Coarse silt ( } \\
\mathrm{kg}^{-1} \text { ) }\end{array}$ & $\mathrm{F}_{6,27}=0.56$ & 0.76 & $143.0 \pm 3.7$ & $116.5 \pm 11.6$ & $128.4 \pm 2.6$ & $123.6 \pm 5.9$ & $123.8 \pm 66.1$ & $81.2 \pm 6.9$ \\
\hline $\begin{array}{l}\text { Fine sand ( } \mathrm{g} \\
\mathrm{kg}^{-1} \text { ) }\end{array}$ & $\mathrm{F}_{6,27}=0.5$ & 0.801 & $202.8 \pm 5.1$ & $239.5 \pm 34.9$ & $218.0 \pm 6.2$ & $205.8 \pm 5.3$ & $224.0 \pm 47.1$ & $234.6 \pm 16.1$ \\
\hline $\begin{array}{l}\text { Coarse sand (g } \\
\mathrm{kg}^{-1} \text { ) }\end{array}$ & $\mathrm{F}_{6,27}=2.91$ & $0.026^{*}$ & $212.2 \pm 13.6 \mathrm{a}$ & $271.0 \pm 26.9 \mathrm{ab}$ & $252.8 \pm 3.4 \mathrm{ab}$ & $289.8 \pm 29.1 \mathrm{ab}$ & $391.6 \pm 118.7 \mathrm{ab}$ & $453.8 \pm 35.5 \mathrm{~b}$ \\
\hline $\begin{array}{l}\text { Total carbon }(\mathrm{g} \\
\left.\mathrm{kg}^{-1}\right)\end{array}$ & $\mathrm{F}_{6,27}=1.1$ & 0.385 & $17.4 \pm 1.4$ & $12.4 \pm 2.1$ & $15.4 \pm 1.9$ & $15.9 \pm 1.6$ & $31.7 \pm 15.6$ & $11.4 \pm 3.2$ \\
\hline $\begin{array}{l}\text { Total nitrogen } \\
\left(\mathrm{g} \mathrm{kg}^{-1}\right)\end{array}$ & $\mathrm{F}_{6,27}=0.72$ & 0.637 & $1.6 \pm 0.1$ & $1.1 \pm 0.2$ & $1.4 \pm 0.1$ & $1.5 \pm 0.2$ & $2.2 \pm 1.3$ & $0.8 \pm 0.3$ \\
\hline $\mathrm{C}: \mathrm{N}$ & $\mathrm{F}_{6,27}=2.72$ & $0.034 *$ & $10.7 \pm 0.3 \mathrm{a}$ & $11.8 \pm 1.8 \mathrm{ab}$ & $10.7 \pm 0.5 \mathrm{ab}$ & $10.9 \pm 0.6 \mathrm{ab}$ & $22.1 \pm 6.2 \mathrm{~b}$ & $15.1 \pm 0.9 \mathrm{ab}$ \\
\hline $\mathrm{pH}$ & $\mathrm{F}_{6,27}=4.31$ & $0.004 * *$ & $7.6 \pm 0.3 \mathrm{a}$ & $8.2 \pm 0.2 \mathrm{ab}$ & $8.3 \pm 0.1 \mathrm{ab}$ & $8.2 \pm 0.1 \mathrm{ab}$ & $8.7 \pm 0.2 \mathrm{~b}$ & $8.6 \pm 0.1 \mathrm{~b}$ \\
\hline $\mathrm{CaCO} 3\left(\mathrm{~g} \mathrm{~kg}^{-1}\right)$ & $\mathrm{X}^{2}=19.38, \mathrm{Df}=$ & $0.004 * * *$ & $5.8 \pm 4.8 \mathrm{a}$ & $70.8 \pm 62.3 \mathrm{a}$ & $20.8 \pm 5.7 \mathrm{a}$ & $58 \pm 46.1 \mathrm{a}$ & $216.6 \pm 20.4 \mathrm{~b}$ & $223.4 \pm 19.1 \mathrm{~b}$ \\
\hline $\mathrm{P} 2 \mathrm{O} 5\left(\mathrm{~g} \mathrm{~kg}^{-1}\right)$ & $\mathrm{X}^{2}=\underset{6}{10.59, \mathrm{Df}=}$ & 0.102 & $0.184 \pm 0.173$ & $0.009 \pm 0.001$ & $0.014 \pm 0.003$ & $0.030 \pm 0.0162$ & $0.016 \pm 0.010$ & $0.026 \pm 0.008$ \\
\hline 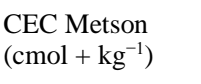 & $\mathrm{F}_{6,27}=1.37$ & 0.261 & $9.1 \pm 0.4$ & $7.1 \pm 1.3$ & $8.4 \pm 0.2$ & $7.8 \pm 0.4$ & $8.7 \pm 4$ & $3.4 \pm 0.6$ \\
\hline $\mathrm{Ca}\left(\mathrm{g} \mathrm{kg}^{-1}\right)$ & $\mathrm{F}_{6,27}=2.89$ & $0.026^{*}$ & $2.8 \pm 1 \mathrm{a}$ & $4.1 \pm 1.1 \mathrm{ab}$ & $4.9 \pm 0.6 \mathrm{ab}$ & $4.3 \pm 1 \mathrm{ab}$ & $6.7 \pm 0.4 \mathrm{~b}$ & $6.4 \pm 0.1 \mathrm{~b}$ \\
\hline $\mathrm{K}\left(\mathrm{g} \mathrm{kg}^{-1}\right)$ & $\mathrm{F}_{6,27}=1.32$ & 0.282 & $0.1 \pm 0$ & $0.1 \pm 0$ & $0.2 \pm 0$ & $0.1 \pm 0$ & $0.1 \pm 0.1$ & $0.1 \pm 0$ \\
\hline
\end{tabular}




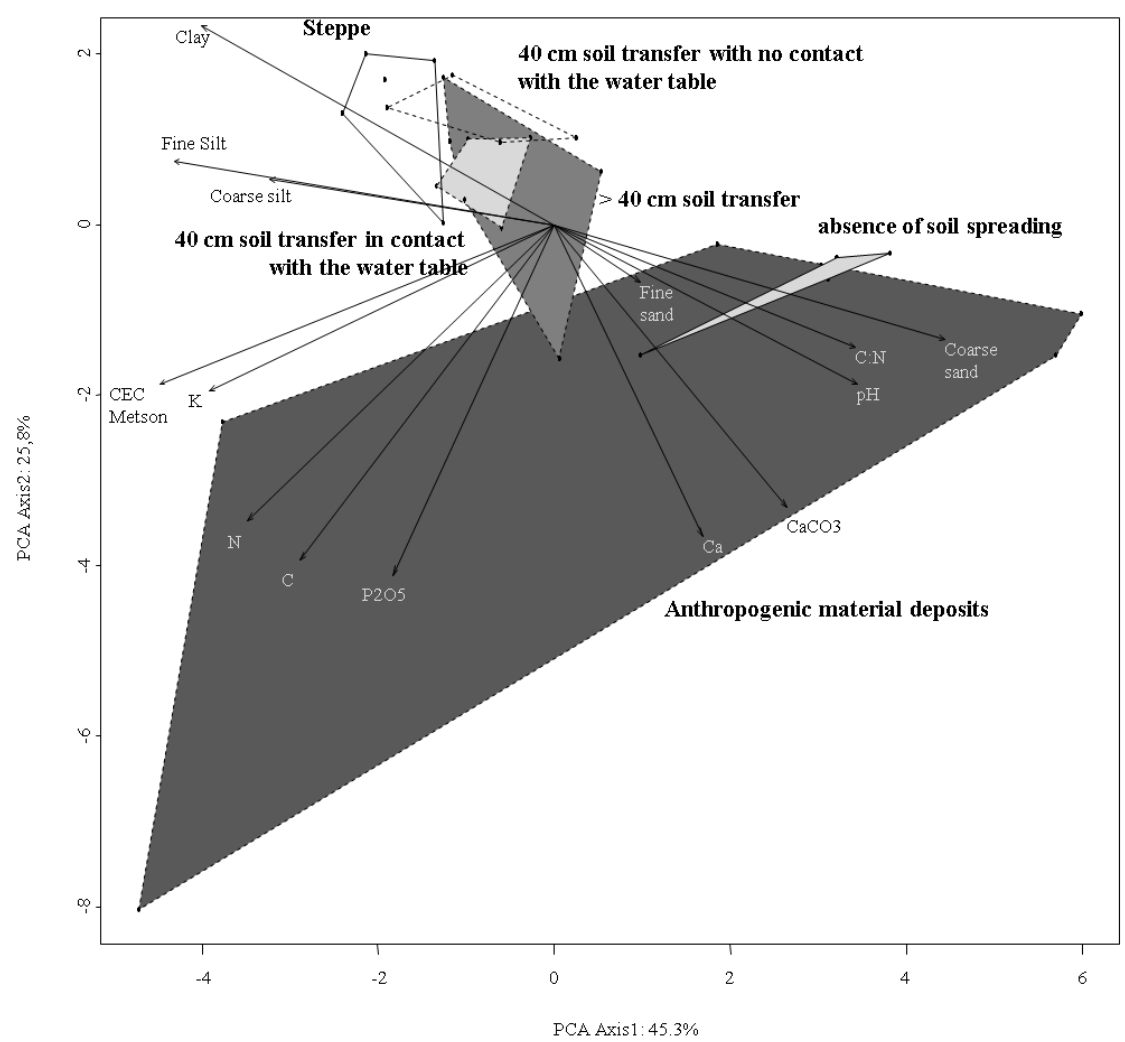

Fig. 3. PCA ordination based on 29 soil sample analyses. Samples from each rehabilitation treatment and control are identified by dashed lines: (1) soil transfer $(40 \mathrm{~cm})$ with no contact with the water table in white (2) soil transfer $(40 \mathrm{~cm})$ in contact with the water table in light grey (3) more than $40 \mathrm{~cm}$ of soil transfer in medium grey and (4) anthropogenic material deposits in dark grey. Both samples from controls are identified by solid lines: Steppe in white, No rehabilitation in grey. Arrows represent soil variables (chemical content (organic $\mathrm{C}$, total $\mathrm{N}, \mathrm{C}: \mathrm{N}, \mathrm{CEC}$ Metson, $\left.\mathrm{K}, \mathrm{P}_{2} \mathrm{O}_{5}, \mathrm{CaCO}_{3}, \mathrm{pH}\right)$ and fine particle sizes $(<2$ $\mathrm{mm})$ (percentages of clay $(<0.002 \mathrm{~mm})$, fine silt $(0.002-0.02 \mathrm{~mm})$, coarse silt $(0.2-2 \mathrm{~mm})$, fine sand $(0.05-$ $0.2 \mathrm{~mm})$ and coarse sand $(0.2-2 \mathrm{~mm}))$

\subsection{Effect of topsoil transfer on plant communities}

\subsubsection{Alpha and gamma diversity}

Vegetation inventories allowed us to identify 21 plant taxa of conservation interest out of the 241 species recorded in total (nearly 10\%): 5 with high conservation priority and 16 with moderate conservation priority on the red list of the Provence-Alpes-Côted'Azur region (Table 3). 224 species were inventoried in the quarries, including 20 regional red list species and 131 in the reference steppe, including 11 regional red list species (Table 3). Only one plant species of conservation interest was identified in the steppe: Phlomis lychnitis L., against 11 in quarries. Four species were recorded in anthropogenic material deposits alone (Bupleurum semicompositum L., Limonium cuspidatum (Delort) Erben, Limonium echioides (L.) Mill., Velezia rigida L.) and one in the negative control (Lythrum hyssopifolia L.) (Table 3). All plant species of conservation interest identified in the topsoil transfer areas were also identified in the reference steppe vegetation, except for Campanula erinus L. and Paronychia capitata (L.) Lam. (Table $3)$. 
Species of conservation interest identified for each treatment in May 2015. The species' regional conservation status was determined from the regional red list of the Provence-Alpes-Côte-d'Azur region

\begin{tabular}{|c|c|c|c|c|c|c|c|}
\hline Species & $\begin{array}{c}\text { Regional } \\
\text { conservation } \\
\text { status }\end{array}$ & $\begin{array}{l}\text { Reference } \\
\text { steppe } \\
\text { (Positive } \\
\text { control) }\end{array}$ & $\begin{array}{c}\text { Topsoil } \\
\text { transfer } \\
(40 \mathrm{~cm}) \\
\text { with no } \\
\text { contact } \\
\text { with the } \\
\text { water } \\
\text { table }\end{array}$ & $\begin{array}{c}\text { Topsoil } \\
\text { transfer } \\
(40 \mathrm{~cm}) \\
\text { in contact } \\
\text { with the } \\
\text { water } \\
\text { table }\end{array}$ & $\begin{array}{c}\text { Topsoil } \\
\text { transfer } \\
\text { (More } \\
\text { than } \\
40 \mathrm{~cm} \text { ) }\end{array}$ & $\begin{array}{c}\text { Anthropogenic } \\
\text { material } \\
\text { deposits }\end{array}$ & $\begin{array}{c}\text { No } \\
\text { rehabilitation } \\
\text { Absence of } \\
\text { soil spreading } \\
\text { /material } \\
\text { deposits } \\
\text { (Negative } \\
\text { control) }\end{array}$ \\
\hline Bupleurum semicompositum $\mathrm{L}$. & Moderate & & & & & $\mathrm{x}$ & \\
\hline Campanula erinus $\mathrm{L}$. & Moderate & & $\mathrm{x}$ & $\mathrm{x}$ & & $\mathrm{x}$ & $\mathrm{x}$ \\
\hline Centaurea melitensis $\mathrm{L}$. & Moderate & $\mathrm{x}$ & & $\mathrm{x}$ & & $\mathrm{x}$ & \\
\hline Gastridium ventricosum (Gouan) Schinz \& Thell. & Moderate & $\mathrm{x}$ & & $\mathrm{x}$ & $\mathrm{x}$ & & \\
\hline Limonium cuspidatum (Delort) Erben & Strong & & & & & $\mathrm{x}$ & \\
\hline Limonium echioides (L.) Mill. & Moderate & & & & & $\mathrm{x}$ & \\
\hline Linaria arvensis (L.) Desf. & Moderate & $\mathrm{x}$ & $\mathrm{x}$ & $\mathrm{x}$ & & $\mathrm{x}$ & \\
\hline Lythrum hyssopifolia $\mathrm{L}$. & Moderate & & & & & & $\mathrm{x}$ \\
\hline Melilotus indicus (L.) All. & Moderate & & & & & $\mathrm{x}$ & \\
\hline Parapholis incurva (L.) C.E.Hubb. & Moderate & $\mathrm{x}$ & & $\mathrm{x}$ & $\mathrm{x}$ & $\mathrm{x}$ & $\mathrm{x}$ \\
\hline Paronychia capitata (L.) Lam. & Moderate & & $\mathrm{x}$ & & & $\mathrm{x}$ & \\
\hline Phlomis lychnitis L. & Moderate & $\mathrm{x}$ & & & & & \\
\hline Polygala monspeliaca $\mathrm{L}$. & Moderate & $\mathrm{x}$ & & & $\mathrm{x}$ & & $\mathrm{x}$ \\
\hline Polypogon maritimus Willd. & Moderate & & & & & $\mathrm{x}$ & $\mathrm{x}$ \\
\hline Psilurus incurvus (Gouan) Schinz \& Thell. & Moderate & $\mathrm{x}$ & $\mathrm{x}$ & $\mathrm{x}$ & $\mathrm{x}$ & $\mathrm{x}$ & $\mathrm{x}$ \\
\hline Ruta Montana (L.) L. & Moderate & $\mathrm{x}$ & $\mathrm{x}$ & & & & \\
\hline Taeniatherum caput-medusae (L.) Nevski & Strong & $\mathrm{x}$ & $\mathrm{x}$ & $\mathrm{x}$ & $\mathrm{x}$ & $\mathrm{x}$ & $\mathrm{x}$ \\
\hline Trifolium glomeratum L. & Strong & $\mathrm{x}$ & $\mathrm{x}$ & $\mathrm{x}$ & & $\mathrm{x}$ & \\
\hline Trifolium subterraneum $\mathrm{L}$. & Moderate & $\mathrm{x}$ & & & $\mathrm{x}$ & & \\
\hline Valerianella microcarpa Loisel. & Strong & & & & $\mathrm{x}$ & $\mathrm{x}$ & \\
\hline Velezia rigida $\mathrm{L}$. & Strong & & & & & $\mathrm{x}$ & \\
\hline
\end{tabular}

At the regional scale (gamma diversity), the mean species richness of the plant communities of the different rehabilitation treatments $(156.78 \pm 0.77)$ was higher than the mean species richness of the reference steppe vegetation $(130 \pm 0)\left(F_{1}, 198=1219, p\right.$ $<0.001$ ). However at the scale of the plant community, the species richness (alpha diversity) of the different topsoil transfer treatments (contact with water table (47.6 \pm $2.02)$; no contact with water table $(36 \pm 1.20)$; more than $40 \mathrm{~cm}$ soil transfer $(35.55 \pm$ 1.46)) showed no significant difference from the vegetation of the reference steppe ( 42.2 \pm 1.51 ) (Fig. 4). In contrast, the average species-richness on anthropogenic material deposits $(29.88 \pm 2.66$ species $)$ and on the negative control $(23.25 \pm 1.64)$ was significantly lower than in the steppe $\left(\mathrm{F}_{5,119}=18.98\right.$, $\left.\mathrm{p}<0.001\right)$ (Fig. 4). 


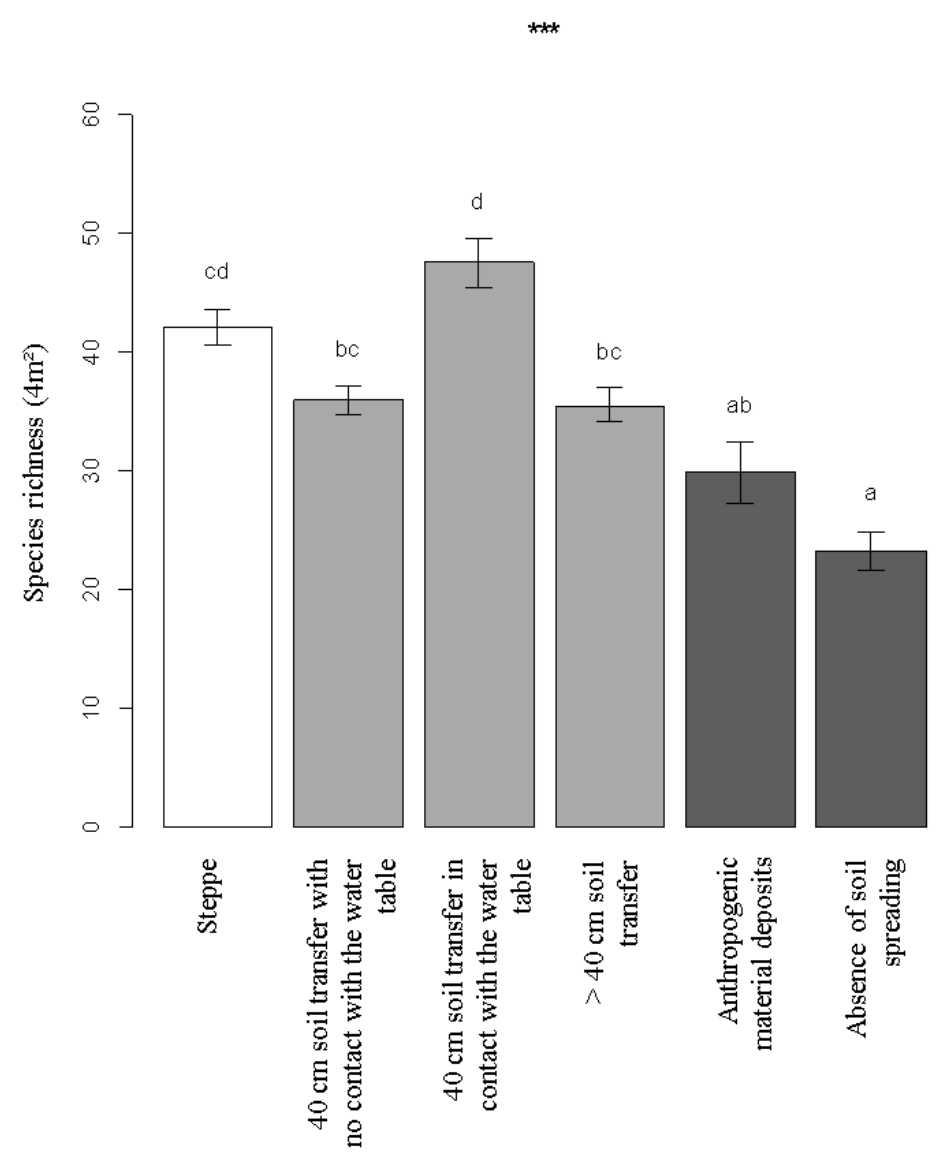

Fig. 4. Means and standard errors of species richness $\left(4 \mathrm{~m}^{2}\right)$ for each treatment and the two controls: steppe (white), topsoil transfer (light grey), anthropogenic material deposits and absence of soil spreading (dark grey). Within a treatment, bars sharing common letters are not significantly different according to Tukey post-hoc test.

\subsubsection{Effects of topsoil transfer on plant community composition}

The NMDS ordination showed a gradient in plant community composition, from the steppe (positive control) to the no-rehabilitation negative control, and clearly discriminated plant communities (NMDS-Stress=0.20) (Fig. 5).

In the NMDS axis1-axis2 plane, the reference steppe was characterized by its most representative species, such as perennial species (Eryngium campestre L., Stipa capillata L., Phlomis lychnitis L., etc.), especially Brachypodium retusum (Pers.) P. Beauv.,usually dominant in the steppe plant community. It was also characterized by annual species such as Aegilops ovata L., Clypeola jonthlaspi L., Cynosurus echinatus L., Hedypnois cretica Willd., Reseda phyteuma L., Stipa capillata L., Trifolium arvense L., which were recorded only in the steppe.

The reference steppe community was close to the two topsoil transfer treatments with no contact with the water table ("> $40 \mathrm{~cm}$ topsoil transfer" and "40 cm topsoil transfer with no contact with the water table") (Fig. 5). These two plant communities overlapped and were characterized mainly by grasses and thistles, such as Avena barbata Brot., and Galactites tomentosus Moench., as well as Euphorbia cyparissias L., Marrubium vulgare L., Medicago truncatula Gaertn., etc.. This was confirmed by the $\mathrm{CSII}_{\text {norm, which showed }}$ that only 18 to $22 \%$ of species identified in topsoil transfer plant communities were also 
present in the steppe community with the same composition, abundance and richness (Fig. 6A) even thirty years after these rehabilitation treatments were applied.

The topsoil transfer in contact with the water table showed a different plant community composition from that of the reference steppe. It contained Anagallis arvensis L., Catapodium rigidum (L.) C.E.Hubbs. , Hypericum perforatum L., Stellaria media (L.) Vill., Veronica arvensis L., etc. (Fig. 5), pioneer species common to anthropogenic and wetland margin environments.

In the NMDS axis1-axis2 plane, the rehabilitated areas (the topsoil transfer and the anthropogenic material deposits treatments) and the reference steppe were also clearly separated from the no-rehabilitation ("negative control") treatment in terms of plant community composition (Fig. 5). The no-rehabilitation control was characterized by pioneer annual target species also occurring in the reference steppe, such as Centranthus calcitrapae (L.) Dufr., Valerianella locusta (L.) Laterr., Velezia rigida L., and other nontarget species such as Artemisia annua L., Pyracantha coccinea M. Roem. (Fig. 5). These last two species can be considered potential invasive species. Due to the presence of the water table, this area contained temporary wetland species such as Lythrum hyssopifolia L., a species of conservation interest.

The plant communities identified in quarries were far from similar to those of the reference steppe $\left(\mathrm{F}_{5} ; 119=227.20, \mathrm{p}<0.001\right)$ (Fig. 6A) in terms of composition, richness and diversity. Not only did they not include all reference steppe species, but they included other species not present in the steppe community (Anagallis foemina Mill., Anagallis arvensis L., Cynodon dactylon (L.) Pers., Dittrichia viscosa (L.) Greuter, Medicago

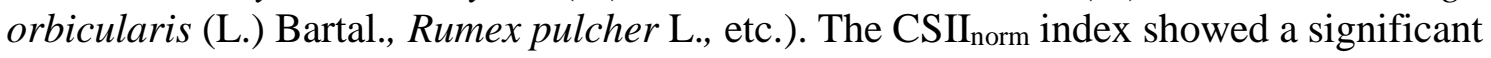
difference between treatments (Fig. 6A). The anthropogenic material deposits treatment and the no-rehabilitation treatment showed a significantly lower $\mathrm{CSII}_{\text {norm }}$ index than the reference steppe (Fig. 6A). The HAI index was relatively high both in the different rehabilitated areas and in the no-rehabilitation treatment, and significantly different from that of the reference steppe $\left(\mathrm{F}_{5,119}=88.66, \mathrm{p}<0.001\right)$ (Fig. 6B). 


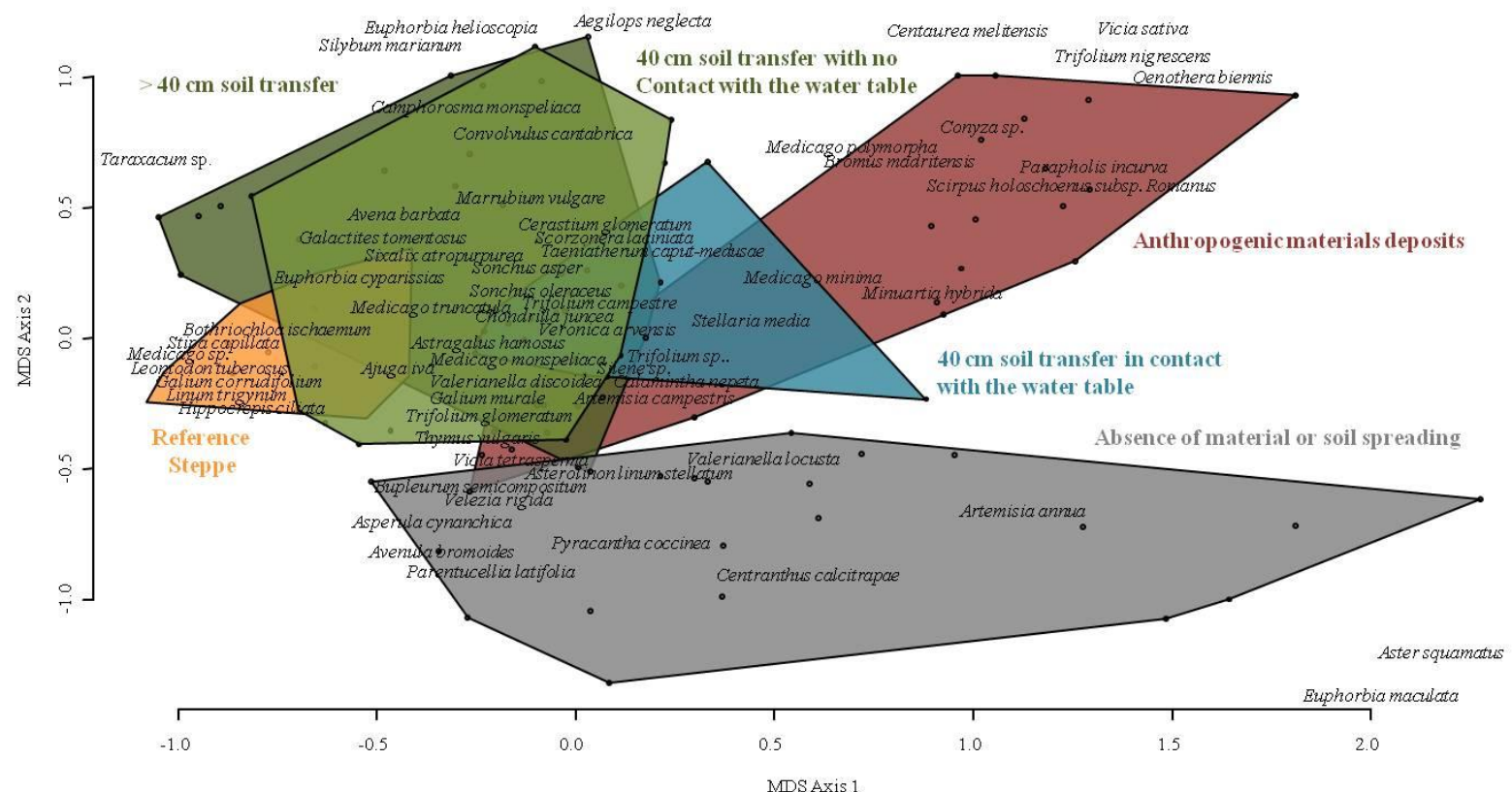

Fig. 5. NMDS ordination based on 125 vegetation samples $\left(4 \mathrm{~m}^{2}\right)$ and 175 species present in at least 3 samples. For clarity, only the 63 most correlated species are shown. Samples from each rehabilitation treatment are identified: (1) soil transfer $(40 \mathrm{~cm})$ with no contact with the water table in light green (2) soil transfer $(40 \mathrm{~cm})$ in contact with the water table in blue (3) more than $40 \mathrm{~cm}$ of soil transfer in dark green and (4) anthropogenic material deposits in red. Both samples from control are identified: steppe in yellow, absence of material or soil spreading in grey.

$$
\text { A }
$$

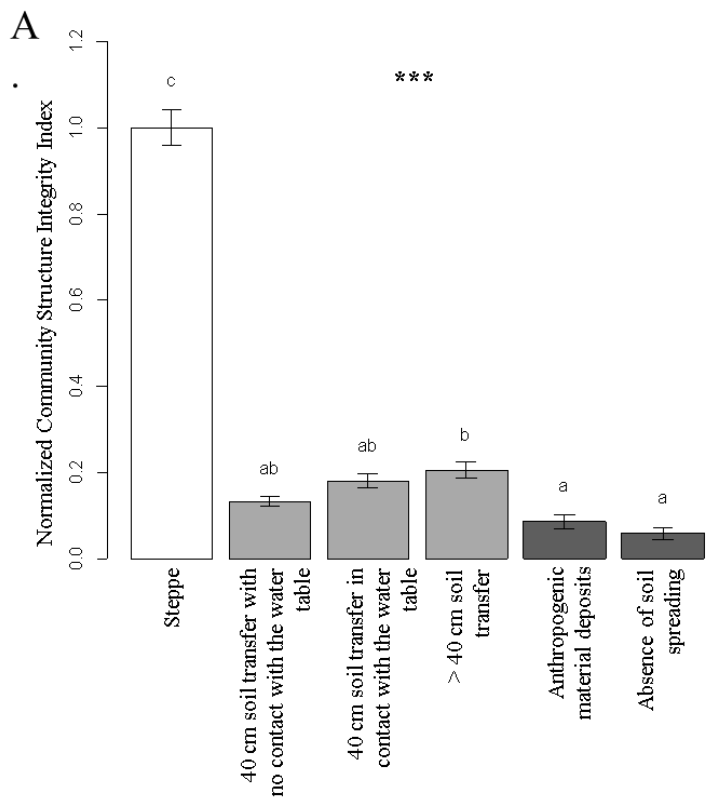

B.

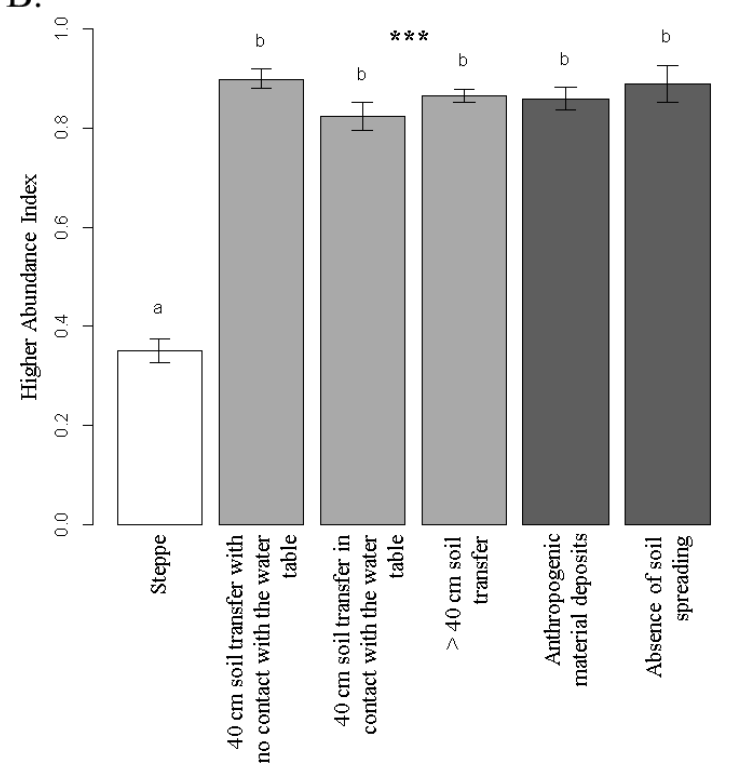

Fig. 6. Means and standard errors of normalized Community Structure Integrity Index (A) and higher Abundance Index (B) for each treatment: steppe (white), topsoil transfer (light grey), anthropogenic material deposits and absence of soil spreading (dark grey). Within a treatment, bars sharing common letters are not significantly different according to Tukey post-hoc test. 


\section{Discussion}

Topsoil transfer has been recognized as the best method for restoring soil and vegetation when this resource has been conserved or is available elsewhere (Box 2014, Bulot et al., 2014, in press). To date, however, the restoration success of this technique has mainly been assessed over the short term (a few years after treatment). Assessing restoration over the long term (several decades), our results show that topsoil transfer is still the best method, especially when initial soil characteristics (thickness, absence of contact with the water table) are respected. Nevertheless, in our case, soil transfer still does not compensate for the destruction of the pre-existing ecosystem: the steppe soil and plant community have not yet fully recovered even thirty years after its application. These results confirm those of Holl and Cairns, Mulligan et al., Nichols (Holl and Cairns, 1994; Mulligan et al., 2006; Nichols, 2006), who found that plant community composition was never completely restored after rehabilitation, in quarries or elsewhere. However, it is generally acknowledged that natural successions towards steppe occur on quarries after topsoil applications and re-vegetation is positive, although species composition still differs from that of the reference steppe (Martínez-Ruiz and Fernández-Santos, 2005).

The negative control, where there was no rehabilitation, no transfer of materials or soil, is the worst situation compared to the undisturbed reference steppe in terms of total number of plant species and total number of plant species of conservation interest. In 30 years, only a fraction of the steppe vegetation has recovered. This is due to the depth of quarrying, which involves potential contact with the water table. New primary plant succession is therefore blocked by irregular changes in ground water table levels, including by the extreme conditions that develop between dry and flood periods (Prach et al., 2014; Balázs A. Lukács et al., 2015; Deák et al., 2015; Masson et al., 2015). The lack of rehabilitation, together with the new abiotic conditions created by quarrying, thus generated "novel ecosystems" (Hobbs et al., 2009). The long-term dynamics of these new ecosystems are unknown, since we have no experience of similar habitat conditions, and because they are also impacted by global change (climate and land-uses) (Doley and Audet, 2013; Hobbs et al., 2013). However, we do know that these environments will not spontaneously evolve towards the reference steppe in the long-term, barring any major ecological change (significant and permanent reduction in the level of the water table). Usually, for these radically disturbed mining sites, it is not practicable to aim for the restoration of historical ecosystems. However, hybrid or novel ecosystems, which consist of new combinations of physical and biological components with new variables and variables common to historical ecosystems, could provide acceptable levels of stability and functionality (Doley and Audet, 2013). For example, vegetation may include both native species and non-native species.

Deposition of various types of anthropogenic materials after the end of quarrying created great heterogeneity in terms of physico-chemical soil parameters, but less diversity and species-richness in terms of vegetation. However, these materials provide some very specific habitats for certain species of high conservation value, which have particular ecological requirements linked to their narrow ecological niche. At some places on our site, depositing sandy salty soils excavated closer to the Mediterranean coast has provided a habitat for Limonium cuspidatum (Delort) Erben and Limonium echioides (L.) Mill., two halophytic species of conservation interest at the regional scale. However, deposition of anthropogenic materials is certainly not the best method to restore plant 
communities similar to the reference steppe in the plain of La Crau. A better method might be steppe geomorphological rehabilitation by filling the bottom of quarry pits, thus isolating the upper transferred soil layers from the water table (Meredith, 2007; Frouz et al., 2008; Mchergui et al., 2014). Nevertheless, our results show that spoils must be covered by at least $40 \mathrm{~cm}$ of topsoil from the reference steppe.

Thus, topsoil transfer appears to be the most favorable treatment for rehabilitation of the reference sub-steppe plant community, in terms of physico-chemical properties and plant community composition. Our long-term results on soil transfer restoration confirm those obtained over the short term by Bulot et al. (2014) and Jaunatre et al. (Jaunatre et al., 2014a, 2014b) for the same steppe area. Our study shows that these reconstituted soils present the most favorable abiotic conditions for restoring the reference steppe, particularly because they entail no significant differences in fine particle size content from the soil of the reference steppe (Buisson et al., 2006; Bulot et al., 2016; Römermann et al., 2005). However, the plant communities identified in these treatments cannot yet be considered similar to those of the reference steppe vegetation, as measured by the various diversity indices. Soil alone does not account for the diversity of vegetation encountered here after different types of soil transfer. Other factors are involved, such as the plant composition of the different surrounding patches, i.e. steppe, abandoned quarries, fallow land, orchards, etc. (Pärtel et al., 1998; Zobel et al., 1998), the reproduction capacity of their communities, the presence of dispersal vectors (Bakker et al., 1996; Ozinga et al., 2004) and between-species competition or facilitation (Maestre et al., 2009; Teixeira et al., 2016). The topsoils transferred most probably had a very poor seed bank, having been conserved in large piles for several years, and the soil of the reference steppe is known to have a very poor permanent seed bank (Römermann et al., 2005; Buisson et al., 2006; Saatkamp et al., 2009; Rivera et al., 2012; Bordez, 2015). Therefore there would be very little similarity between the topsoil transferred and the reference steppe seed banks. Soil transfers in contact with the water table are ruled out as a restoration treatment aiming to restore the vegetation from the reference steppe (Mediterranean xeric grasslands), since they favor species adapted to moist soils, such as Scirpus holoschoenus subsp. romanus (L.) auct., Aster squamatus (Sperng.) Hieron, etc.. The solution would be to reconstitute the conglomerate bedrock occurring in the reference steppe, or to deposit spoil materials covered by topsoil as described above, which would prevent plant roots from reaching the water table.

Compared to techniques that only impact species dispersion, such as hay transfer (Hölzel and Otte, 2003; Coiffait-Gombault et al., 2011a, 2011b; Török et al., 2012) or seeding (Oliveira et al., 2014; Gilardelli et al., 2016), topsoil transfer offers the best results,,both by dispersing target species and by at least partially recreating soil abiotic conditions (Box, 2003; Jaunatre et al., 2014b). However, real success is only possible if certain criteria are met. The topsoil's particle size fraction needs to be adequate and it should not contain blocks of conglomerate that will raise soil $\mathrm{CaCO}_{3}$ content. This could negatively impact some slightly acidophilus species which characterize the steppe vegetation, especially "tonsures" (vegetation patches composed of very small vegetation, dominated by bryophytes, lichens and vascular plants that are more acidophilus and xerophilous than other steppe species (Coiffait-Gombault, 2011)).

Confirming findings by Simón-Torrez et al. (Simón-Torres et al., 2014), our study demonstrates that in the long term, the best way to restore the reference steppe vegetation is by using the most similar soil, which has conserved its fine particle size fraction, with a thickness 
of at least 30 to $40 \mathrm{~cm}$ and without contact with the water table (Redente et al., 1997; Holmes, 2001; Bowen et al., 2005). Schladweiler et al. (Schladweiler et al., 2005) found that $30 \mathrm{~cm}$ of topsoil produced the greatest diversity; while they found that more than $50 \mathrm{~cm}$ ensured the greatest biomass, this was not our goal here. Despite topsoil transfer, 30 years was not sufficient to reach the reference state, even though the traditional sheep-grazing regime was re-established after quarry abandonment. Other factors may have been involved in changing the plant succession. At soil level, fine elements such as clays could have been lost by leaching during soil transport and / or the storage phase (Weng et al., 2004; Zeng et al., 2011). This would have modified soil physico-chemical properties and consequently the plant communities that developed there (Citeau, 2008; Amir et al., 2014). On our soil transfer treatments, species richness was similar to the steppe, but the most dominant species of the steppe was still absent (Brachypodium retusum). Conversely, species not present in the steppe were able to develop. In all cases, our monitoring should be pursued on the long-term. There is clearly room for improvement in the methods used for future restoration of quarries still in operation. Topsoil transfer in turfs could be one answer (Good et al., 1999; Vécrin and Muller, 2003; Bulot et al., 2014), as this method allows the conservation of the soil structure (Bulot et al., 2014). The transfer could also be direct, without storage, thereby limiting degradation of the soil and of the seed bank (Granstrom, 1987; Jones and Esler, 2004; Fenner and Thompson, 2005; Hall et al., 2010; Golos and Dixon, 2014). This would also ensure that plant species remain established on the turfs, preventing undesired species implantation. Although direct topsoil transfer is advocated, it is often not feasible because soil in place in the steppe may not be available when required for transfer (Bulot et al., 2014). When only ordinary soil transfer is possible, storage time must be as short as possible: numerous studies have shown the negative impact of soil storage (Strohmayer, 1999; Stahl et al., 2002; Boyer et al., 2011; Park et al., 2011; Golos and Dixon, 2014; Bordez, 2015). Storage can lead to negative impacts on the soil seed bank. Direct topsoil transfer results in loss of less than 50\% of the soil seed bank, whereas stockpiling causes loss of 80-90\% (Koch et al., 1996). In addition, stored soil piles form a barrier and can trap many nontarget anemochorous species (Bordez, 2015). Storage can also cause rotting of organic matter when piles are too high (Stahl et al., 2002). It is therefore recommended that soil be stored on low elevation piles (Bordez, 2015). Moreover, while soil transfer may go some way toward restoring the reference ecosystem, the trajectories of rehabilitated ecosystems are not those of the reference steppe ecosystem. Additional techniques should be implemented to enhance restoration, such as seeding target species or removing undesirable species (Bordez, 2015). For example, native species seeding favors the development of native species to the detriment of exotic or ruderal species (Norman et al., 2006).

In conclusion, topsoil transfer methods can be enhanced by various techniques offering prospects of improved restoration. This should encourage current quarrying operations to implement these findings when planning for rehabilitation.

\section{Acknowledgements}

This study was supported by Gagneraud construction funding. We would like to thank the Réserve Naturelle Nationale des Coussous de Crau and the Grand Port Maritime de Marseille in Fos-sur-Mer for permission to access the study site. We thank Pierre Bourguet and Jean-Marc Arnal (Société des Carrières de la Ménudelle) for their 
collaboration. We are also grateful to students, technicians, research assistants, field ecologists for help with field work: Anne Aurière, Cannelle Moinardeau, Hervé Ramone, Manon Hess, Elie Gaget and Daniel Pavon.

\section{References}

Allison, L.E., 1965. Organic carbon, in: Black, C.A., Evans, D.D., White, J.L., Enisminger L.E., \& Clark, F.E., 1965. Methods of Soil Analysis. American Society of Agronomy, Madison, Wisconsin, pp. 1372-1378.

Amir, H., L'Huillier, L., Fogliani, B., Cavaloc, Y., Gensous, S., Jourand, P., Ducousso, M., Majorel, C., Hannibal, L., Saintpierre, D., Gunkel-Grillon, P., Pagand, P., Echevarria, G., Mouchon, L.-C., Bonis, M.-L., Montarges-Pelletier, E., Maggia, L., Wulff, A., 2014. Caractérisation et fonctionnement du système sol/ plante/ microorganismes dans les maquis miniers. Perspectives d'application à la restauration écologique.

Badan, O., Congés, G., Brun, J.-P., 1995. Les bergeries romaines de la Crau d'Arles. Les origines de la transhumance en Provence. Gallia 52, 263-310. doi:10.3406/galia.1995.3152

Bakker, J.P., Poschlod, P., Strykstra, R.J., Bekker, R.M., Thompson, K., 1996. Seed banks and seed dispersal: important topics in restoration ecology§. Acta Botanica Neerlandica 45, 461-490. doi:10.1111/j.1438-8677.1996.tb00806.x

Balázs A. Lukács, Péter Török, András Kelemen, Gábor Várbíró, Szilvia Radócz, Tamás Miglécz, Béla Tóthmérész, Orsolya Valkó, 2015. Rainfall fluctuations and vegetation patterns in alkali grasslands - using self-organizing maps to visualise vegetation dynamics. doi:10.14471/2015.35.011

Ballesteros, M., Cañadas, E.M., Foronda, A., Peñas, J., Valle, F., Lorite, J., 2014. Central role of bedding materials for gypsum-quarry restoration: An experimental planting of gypsophile species. Ecological Engineering 70, 470-476. doi:10.1016/j.ecoleng.2014.06.001

Bonferroni, C.E., 1936. Teoria statistica delle classi e calcolo delle probabilità. Pubblicazioni del R Istituto Superiore di Scienze Economiche e Commerciali di Firenze 8, 1-62.

Borcard, D., Gillet, F., Legendre, P., 2011. Numerical Ecology with R. Springer New York, New York, NY.

Bordez, L., 2015. Stratégies de revégétalisation des maquis miniers nickélifères de Nouvelle-Calédonie étude sur les potentiels biologiques des Topsoils en vue de leur utilisation pour la restauration écologique des milieux dégradés aplication au massif de Koniembo pour KNS. (phdthesis). Institut Agronomique Néocalédonien, Nouvelle Calédonie.

Bowen, C.K., Schuman, G.E., Olson, R.A., Ingram, J., 2005. Influence of Topsoil Depth on Plant and Soil Attributes of 24-Year Old Reclaimed Mined Lands. Arid Land Research and Management 19, 267-284. doi:10.1080/15324980590951441

Box, J., 2014. Habitat translocation, rebuilding biodiversity and no net loss of biodiversity. Water Environ J 28, 540-546. doi:10.1111/wej.12077

Box, J., 2003. Critical Factors and Evaluation Criteria for Habitat Translocation. Journal of Environmental Planning and Management 46, 839-856. doi:10.1080/0964056032000157624

Boyer, S., Wratten, S., Pizey, M., Weber, P., 2011. Impact of soil stockpiling and mining rehabilitation on earthworm communities. Pedobiologia, 9th International 
Symposium on Earthworm EcologyXalapa, Veracruz, Mexico, 5th - 10th September 2010 54, Supplement, S99-S102. doi:10.1016/j.pedobi.2011.09.006

Bremner, J.M., 1996. Nitrogen-Total, in: Sparks, D.L., Page, A.L., Helmke, P.A., Loeppert, R.H., Soltanpour, P.N., Tabatabai, M.A., Johnston, C.T., \& Sumner, M.E., 1996. Methods of Soil Analysis. Part 3 - Chemical Methods. Soil Science Society of America Book Series, pp. 1085-1121.

Buisson, E., Dutoit, T., 2006. Creation of the natural reserve of La Crau: Implications for the creation and management of protected areas. Journal of Environmental Management 80, 318-326. doi:10.1016/j.jenvman.2005.09.013

Buisson, E., Dutoit, T., Torre, F., Römermann, C., Poschlod, P., 2006. The implications of seed rain and seed bank patterns for plant succession at the edges of abandoned fields in Mediterranean landscapes. Agriculture, Ecosystems \& Environment 115, 6-14. doi:10.1016/j.agee.2005.12.003

Bulot, A., Potard, K., Bureau, F., Bérard, A., Dutoit, T., 2016. Ecological restoration by soil transfer: impacts on restored soil profiles and topsoil functions. Restor Ecol n/a-n/a. doi:10.1111/rec.12424

Bulot, A., Provost, E., Dutoit, T., 2014. A comparison of different soil transfer strategies for restoring a Mediterranean steppe after a pipeline leak (La Crau plain, SouthEastern France). Ecological Engineering 71, 690-702. doi:10.1016/j.ecoleng.2014.07.060

Carrick, P.J., Krüger, R., 2007. Restoring degraded landscapes in lowland Namaqualand: Lessons from the mining experience and from regional ecological dynamics. Journal of Arid Environments, Special Issue Sustainable Land Use in Namaqualand 70, 767-781. doi:10.1016/j.jaridenv.2006.08.006

Chapel, A.G., 2011. La biodiversité dans les carrières, une réalité ? Avis des associations naturalistes. doi:urn:doi:10.4000/vertigo.10702

Cherel, O., 1988. Contribution à l'étude des relations végétation-mouton sur les parcours de Crau (S. E. France) : adaptation et développement de méthodes d'étude du régime alimentaire. Université Aix Marseille 1, Marseille.

Chessel, D., Dufour, A.-B., Thioulouse, J., 2004. The ade4 package - I: One-table methods. R News 4, 5-10.

Ciesielski, H., Sterckeman, T., Santerne, M., Willery, J.P., 1997. A comparison between three methods for the determination of cation exchange capacity and exchangeable cations in soils. Agronomy for Sustainable Development 17, 9-15. doi:10.1051/agro:19970102

Citeau, L., 2008. Gestion durable des sols. Éditions Quæ, Versailles.

Coiffait-Gombault, C., 2011. Règles d'assemblages et restauration écologique des communautés végétales herbacées méditerranéennes : le cas de la Plaine de La Crau (Bouches-du-Rhône, France) (phdthesis). Université d'Avignon, Avignon.

Coiffait-Gombault, C., Buisson, E., Dutoit, T., 2011a. Hay transfer and sowing structuring species: Two complementary ecological engineering techniques to restore dry grassland communities. Procedia Environmental Sciences, Ecological Engineering: from Concepts to Applications, Paris 2009 9, 33-39. doi:10.1016/j.proenv.2011.11.007

Coiffait-Gombault, C., Buisson, E., Dutoit, T., 2011b. Hay Transfer Promotes Establishment of Mediterranean Steppe Vegetation on Soil Disturbed by Pipeline Construction. Restoration Ecology 19, 214-222. doi:10.1111/j.1526100X.2010.00706.x 
Cooke, J.A., Johnson, M.S., 2002. Ecological restoration of land with particular reference to the mining of metals and industrial minerals: A review of theory and practice. Environmental Reviews 10, 41-71.

Corbett, E.A., Anderson, R.C., Rodgers, C.S., 1996. Prairie Revegetation of a Strip Mine in Illinois: Fifteen Years after Establishment. Restoration Ecology 4, 346-354. doi:10.1111/j.1526-100X.1996.tb00187.x

Damigos, D., Kaliampakos, D., 2003. Assessing the benefits of reclaiming urban quarries: a CVM analysis. Landscape and Urban Planning 64, 249-258. doi:10.1016/S0169-2046(02)00243-8

D’Antonio, C., Meyerson, L.A., 2002. Exotic Plant Species as Problems and Solutions in Ecological Restoration: A Synthesis. Restoration Ecology 10, 703-713. doi:10.1046/j.1526-100X.2002.01051.x

Deák, B., Valkó, O., Török, P., Kelemen, A., Miglécz, T., Szabó, S., Szabó, G., Tóthmérész, B., 2015. Micro-topographic heterogeneity increases plant diversity in old stages of restored grasslands. Basic and Applied Ecology 16, 291-299. doi:10.1016/j.baae.2015.02.008

DITR, 2005. Mine Closure and Completion: Leading Practice Sustainable Development Program for the Mining Industry, Australian Government. ed. Department of Industry Tourism and Resources, Canberra.

Doley, D., Audet, P., 2013. Adopting novel ecosystems as suitable rehabilitation alternatives for former mine sites. Ecological Processes 2, 22. doi:10.1186/21921709-2-22

Dontala, S.P., Reddy, T.B., Vadde, R., 2015. Environmental Aspects and Impacts its Mitigation Measures of Corporate Coal Mining. Procedia Earth and Planetary Science, Global Challenges, Policy Framework \& Sustainable Development for Mining of Mineral and Fossil Energy Resources (GCPF:2015-20) 11, 2-7. doi:10.1016/j.proeps.2015.06.002

Dray, S., Dufour, A.-B., 2007. The ade4 Package: Implementing the Duality Diagram for Ecologists. Journal of Statistical Software 1-20.

Dray, S., Dufour, A.B., Chessel, D., 2007. The ade4 Package--II: Two-table and K-table Methods. R News 7, 47-52.

Dutoit, T., Buisson, E., Fadda, S., Henry, F., Coiffait-Gombault, C., Jaunatre, R., Alignan, J.-F., Masson, S., Bulot, A., 2013. The pseudo-steppe of La Crau (South-Eastern France): origin, management and restoration of a Mediterranean rangeland, in: Traba, J., Morales, M, (Eds.). Steppe Ecosystems: Biological Diversity, Management and Restoration. Nova Publishers, USA, p. 347.

El-Taher, A., García-Tenorio, R., Khater, A.E.M., 2016. Ecological impacts of AlJalamid phosphate mining, Saudi Arabia: Soil elemental characterization and spatial distribution with INAA. Applied Radiation and Isotopes 107, 382-390. doi:10.1016/j.apradiso.2015.11.019

European Parliament, 2014. Directive 2014/52/EU of the European Parliament andof the Council of 16 April 2014 amending Directive 2011/92/EU on the assessment of the effects of certain public and private projects on the environment.

Fenner, M., Thompson, K., 2005. The ecology of seeds. Cambridge University Press, Cambridge, UK; New York, NY, USA.

Fowler, W.M., Fontaine, J.B., Enright, N.J., Veber, W.P., 2015. Evaluating restoration potential of transferred topsoil. Appl Veg Sci 18, 379-390. doi:10.1111/avsc. 12162 
Frouz, J., Prach, K., Pižl, V., Háněl, L., Starý, J., Tajovský, K., Materna, J., Balík, V., Kalčík, J., Řehounková, K., 2008. Interactions between soil development, vegetation and soil fauna during spontaneous succession in post mining sites. European Journal of Soil Biology 44, 109-121. doi:10.1016/j.ejsobi.2007.09.002

Gaucherand, S., Cooper, D.., Hazen, C., Jaunatre, R., in press. Are short-term success criteria useful metrics to evaluate wetland restoration in a Rocky Mountain recreational complex. Environmental Management.

Gee, G.W., Bauder, J.W., 1986. Particle-size Analysis, in: Particle-Size Analysis. Klute, Madison, Wisconsin, pp. 383-411.

Ghose, M., 2001. Management of topsoil for geo-environmental reclamation of coal mining areas. Env Geol 40, 1405-1410. doi:10.1007/s002540100321

Gilardelli, F., Sgorbati, S., Citterio, S., Gentili, R., 2016. Restoring Limestone Quarries: Hayseed, Commercial Seed Mixture or Spontaneous Succession? Land Degrad. Develop. 27, 316-324. doi:10.1002/ldr.2244

Gillet, F., 2000. La phytosociologie synusiale intégrée. Guide méthodologique. Université de Neuchâtel, Laboratoire d'écologie végétale et de phytosociologie 68.

Golos, P.J., Dixon, K.W., 2014. Waterproofing Topsoil Stockpiles Minimizes Viability Decline in the Soil Seed Bank in an Arid Environment. Restor Ecol 22, 495-501. doi: $10.1111 /$ rec. 12090

Good, J.E.G., Wallace, H.L., Stevens, P.A., Radford, G.L., 1999. Translocation of HerbRich Grassland from a Site in Wales Prior to Opencast Coal Extraction. Restoration Ecology 7, 336-347. doi:10.1046/j.1526-100X.1999.72028.x

Granstrom, A., 1987. Seed Viability of Fourteen Species During Five Years of Storage in a Forest Soil. Journal of Ecology 75, 321-331. doi:10.2307/2260421

Hall, S.L., Barton, C.D., Baskin, C.C., 2010. Topsoil Seed Bank of an Oak-Hickory Forest in Eastern Kentucky as a Restoration Tool on Surface Mines. Restoration Ecology 18, 834-842. doi:10.1111/j.1526-100X.2008.00509.x

Henry, F., 2009. Origine et dynamique à long terme d'un écosystème herbacé pseudo steppique, le cas de la plaine de La Crau (Bouches du Rhône, France). Université Paul-Cézanne, Marseille.

Henry, F., Talon, B., Dutoit, T., 2010. The age and history of the French Mediterranean steppe revisited by soil wood charcoal analysis. The Holocene 20, 25-34. doi:10.1177/0959683609348841

Herrick, J.E., Schuman, G.E., Rango, A., 2006. Monitoring ecological processes for restoration projects. Journal for Nature Conservation 14, 161-171. doi:10.1016/j.jnc.2006.05.001

Hobbs, R.J., Higgs, E., Harris, J.A., 2009. Novel ecosystems: implications for conservation and restoration. Trends in Ecology \& Evolution 24, 599-605. doi:10.1016/j.tree.2009.05.012

Hobbs, R.J., Higgs, E.S., Hall, C., 2013. Novel Ecosystems: Intervening in the New Ecological World Order. Wiley-Blackwell, Chichester, UK.

Holl, K.D., Cairns, J., 1994. Vegetational Community Development on Reclaimed Coal Surface Mines in Virginia. Bulletin of the Torrey Botanical Club 121, 327-337. doi: $10.2307 / 2997006$

Holmes, P.M., 2001. Shrubland Restoration Following Woody Alien Invasion and Mining: Effects of Topsoil Depth, Seed Source, and Fertilizer Addition. Restoration Ecology 9, 71-84. doi:10.1046/j.1526-100x.2001.009001071.x 
Hölzel, N., Otte, A., 2003. Restoration of a species-rich flood meadow by topsoil removal and diaspore transfer with plant material. Applied Vegetation Science 6, 131-140. doi:10.1111/j.1654-109X.2003.tb00573.x

IUSS Working Group WRB (Ed.), 2006. World reference base for soil resources 2006: a framework for international classification, correlation and communication, World soil resources reports. Food and Agriculture Organization of the United Nations, Rome.

Jaunatre, R., Buisson, E., Dutoit, T., 2014a. Topsoil removal improves various restoration treatments of a Mediterranean steppe (La Crau, southeast France). Appl Veg Sci 17, 236-245. doi:10.1111/avsc. 12063

Jaunatre, R., Buisson, E., Dutoit, T., 2014b. Can ecological engineering restore Mediterranean rangeland after intensive cultivation? A large-scale experiment in southern France. Ecological Engineering 64, 202-212. doi:10.1016/j.ecoleng.2013.12.022

Jaunatre, R., Buisson, E., Muller, I., Morlon, H., Mesléard, F., Dutoit, T., 2013. New synthetic indicators to assess community resilience and restoration success. Ecological Indicators 29, 468-477. doi:10.1016/j.ecolind.2013.01.023

Jones, F.E., Esler, K.J., 2004. Relationship between soil-stored seed banks and degradation in eastern Nama Karoo rangelands (South Africa). Biodiversity and Conservation 13, 2027-2053. doi:10.1023/B:BIOC.0000040007.33950.38

Koch, J.M., 2007. Restoring a Jarrah Forest Understorey Vegetation after Bauxite Mining in Western Australia. Restoration Ecology 15, S26-S39. doi:10.1111/j.1526100X.2007.00290.X

Koch, J.M., Ward, S.C., Grant, C.D., Ainsworth, G.L., 1996. Effects of Bauxite Mine Restoration Operations on Topsoil Seed Reserves in the Jarrah Forest of Western Australia. Restoration Ecology 4, 368-376. doi:10.1111/j.1526100X.1996.tb00189.x

Lebaudy, G., 2004. Gravures et graffiti des bergers de la plaine de la Crau: un patrimoine fragile et méconnu. Ecologia mediterranea: Revue internationale d'écologie méditerranéenne = International Journal of Mediterranean Ecology 30, 35-45.

Maestre, F.T., Callaway, R.M., Valladares, F., Lortie, C.J., 2009. Refining the stressgradient hypothesis for competition and facilitation in plant communities. Journal of Ecology 97, 199-205. doi:10.1111/j.1365-2745.2008.01476.x

Martínez-Ruiz, C., Fernández-Santos, B., 2005. Natural revegetation on topsoiled mining-spoils according to the exposure. Acta Oecologica 28, 231-238. doi:10.1016/j.actao.2005.05.001

Masson, S., Mesléard, F., Dutoit, T., 2015. Using Shrub Clearing, Draining, and Herbivory to Control Bramble Invasion in Mediterranean Dry Grasslands. Environmental Management 56, 933-945. doi:10.1007/s00267-015-0541-x

Mchergui, C., Aubert, M., Buatois, B., Akpa-Vinceslas, M., Langlois, E., Bertolone, C., Lafite, R., Samson, S., Bureau, F., 2014. Use of dredged sediments for soil creation in the Seine estuary (France): Importance of a soil functioning survey to assess the success of wetland restoration in floodplains. Ecological Engineering 71, 628-638. doi:10.1016/j.ecoleng.2014.07.064

Meredith, K.R., 2007. The influence of soil reconstruction methods on mineral sands mine soil properties. Faculty of the Virginia Polytechnic Institute and State University, Virginia. 
Metson, A.J., 1956. Methods of chemical analysis for soil survey samples. New Zealand Department of Scientific and Industrial Research.

Milgrom, T., 2008. Environmental aspects of rehabilitating abandoned quarries: Israel as a case study. Landscape and Urban Planning 87, 172-179. doi:10.1016/j.landurbplan.2008.06.007

Misra, A.K., 2013. Influence of stone quarries on groundwater quality and health in Fatehpur Sikri, India. International Journal of Sustainable Built Environment 2, 73-88. doi:10.1016/j.ijsbe.2013.11.002

Mohamed, A.M.E., Mohamed, A.E.-E.A., 2013. Quarry blasts assessment and their environmental impacts on the nearby oil pipelines, southeast of Helwan City, Egypt. NRIAG Journal of Astronomy and Geophysics 2, 102-115. doi:10.1016/j.nrjag.2013.06.013

Molinier, R., Tallon, G., 1950. La végétation de la Crau (Basse-Provence). Librairie générale de l'enseignement, Paris, France.

Molliex, S., Siame, L.L., Bourlès, D.L., Bellier, O., Braucher, R., Clauzon, G., 2013. Quaternary evolution of a large alluvial fan in a periglacial setting (Crau Plain, SE France) constrained by terrestrial cosmogenic nuclide (10Be). Geomorphology 195, 45-52. doi:10.1016/j.geomorph.2013.04.025

Mouflis, G.D., Gitas, I.Z., Iliadou, S., Mitri, G.H., 2008. Assessment of the visual impact of marble quarry expansion (1984-2000) on the landscape of Thasos island, NE Greece. Landscape and Urban Planning 86, 92-102. doi:10.1016/j.landurbplan.2007.12.009

Muller, I., Buisson, E., Mouronval, J.-B., Mesléard, F., 2013. Temporary wetland restoration after rice cultivation: is soil transfer required for aquatic plant colonization? Knowledge and Management of Aquatic Ecosystems 3. doi:10.1051/kmae/2013067

Mulligan, D.R., Gillespie, M.J., Gravina, A.J., Currey, A., 2006. An assessment of the direct revegetation strategy on the tailings storage facility at Kidston gold mine, North Queensland, Australia, in: Fourie, A., Tibbett, M., 2006. Mine Closure 2006: Proceedings of the First International Seminar on Mine Closure. Australian Centre for Geomechanics, Perth WA, pp. 371-381.

Nichols, O.G., 2006. Developing completion criteria for native ecosystem reconstruction: A challenge for the mining industry, in: Fourie, A., Tibbett, M., 2006. Mine Closure 2006: Proceedings of the First International Seminar on Mine Closure. Australian Centre for Geomechanics, Perth WA, pp. 61-74.

Noble, V., Van Es, J., Michaud, H., Garraud, L., 2015. Liste Rouge de la flore vasculaire de Provence-Alpes-Côte d'Azur.

Norman, M.A., Koch, J.M., Grant, C.D., Morald, T.K., Ward, S.C., 2006. Vegetation Succession After Bauxite Mining in Western Australia. Restoration Ecology 14, 278-288. doi:10.1111/j.1526-100X.2006.00130.x

Oksanen, J.F., Blanchet, G., Kindt, R., Legendre, P., Minchin, P.R., O'Hara, R.B., Simpson, G.L., Solymos, P., Henry, M., Stevens, H., Wagner, H., 2015. Package "vegan": Community Ecology Package. R package version 2.3-2 285.

Oliveira, G., Clemente, A., Nunes, A., Correia, O., 2014. Suitability and limitations of native species for seed mixtures to re-vegetate degraded areas. Appl Veg Sci 17, 726-736. doi:10.1111/avsc. 12099

Oliveira, G., Nunes, A., Clemente, A., Correia, O., 2011. Effect of substrate treatments on survival and growth of Mediterranean shrubs in a revegetated quarry: An eight- 
year study. Ecological Engineering $37, \quad 255-259$. doi:10.1016/j.ecoleng.2010.11.015

Olsen, S.R. (Sterling R., 1954. Estimation of available phosphorus in soils by extraction with sodium bicarbonate. Washington, D.C. : U.S. Dept. of Agriculture.

Ozinga, W.A., Bekker, R.M., Schaminée, J.H.J., Van Groenendael, J.M., 2004. Dispersal potential in plant communities depends on environmental conditions. Journal of Ecology 92, 767-777. doi:10.1111/j.0022-0477.2004.00916.x

Park, S.-G., Yi, M.-H., Shin, H.-T., Kurosawa, K., 黒澤靖, 2011. Temporal Change of Soil Animals of the Stockpiled Forest Topsoil in Relation to Soil Temperature and Soil Moisture. Journal of the Faculty of Agriculture, Kyushu University 56, 9-13.

Pärtel, M., Kalamees, R., Zobel, M., Rosén, E., 1998. Restoration of species-rich limestone grassland communities from overgrown land: the importance of propagule availability. Ecological Engineering 10, 275-286. doi:10.1016/S09258574(98)00014-7

Pinto, V., Font, X., Salgot, M., Tapias, J., Mañá, T., 2001. Image analysis applied to quantitative evaluation of chromatic impact generated by open-pit quarries and mines. Env Geol 41, 495-503. doi:10.1007/s002540100259

Pitz, C., Piqueray, J., Harzé, M., Seleck, M., Boisson, S., Le Stradic, S., Mahy, G., 2014. Etude de la flore spontanée de la carrière de Loën pour de futures restaurations Rapport final.

Prach, K., Lencová, K., Řehounková, K., Dvořáková, H., Jírová, A., Konvalinková, P., Mudrák, O., Novák, J., Trnková, R., 2013. Spontaneous vegetation succession at different central European mining sites: a comparison across seres. Environ Sci Pollut Res 20, 7680-7685. doi:10.1007/s11356-013-1563-7

Prach, K., Řehounková, K., Lencová, K., Jírová, A., Konvalinková, P., Mudrák, O., Študent, V., Vaněček, Z., Tichý, L., Petř́k, P., Šmilauer, P., Pyšek, P., 2014. Vegetation succession in restoration of disturbed sites in Central Europe: the direction of succession and species richness across 19 seres. Appl Veg Sci 17, 193-200. doi:10.1111/avsc. 12064

R Development Core Team, 2011. R: a language and environment for statistical computing. the R Foundation for Statistical Computing, Vienna, Austria.

Redente, E.F., Mclendon, T., Agnew, W., 1997. Influence of topsoil depth on plant community dynamics of a seeded site in northwest Colorado. Arid Soil Research and Rehabilitation 11, 139-149. doi:10.1080/15324989709381467

Remacle, A., 2009. Contribution des anciennes carrières à la biodiversité wallonne: rapport de convention (C45) [Les carrières en Région wallonne : inventaire et intérêt biologique]. Service public de Wallonie, Direction générale opérationnelle de l'Agriculture, des Ressources naturelles et de l'Environnement, Direction de la Nature 129.

Rivera, D., Jáuregui, B.M., Peco, B., 2012. The fate of herbaceous seeds during topsoil stockpiling: Restoration potential of seed banks. Ecological Engineering 44, 94101. doi:10.1016/j.ecoleng.2012.03.005

Rivera, D., Mejías, V., Jáuregui, B.M., Costa-Tenorio, M., López-Archilla, A.I., Peco, B., 2014. Spreading Topsoil Encourages Ecological Restoration on Embankments: Soil Fertility, Microbial Activity and Vegetation Cover. PLOS ONE 9, e101413. doi:10.1371/journal.pone.0101413 
Römermann, C., Tackenberg, O., Poschlod, P., 2005. How to predict attachment potential of seeds to sheep and cattle coat from simple morphological seed traits. Oikos 110, 219-230. doi:10.1111/j.0030-1299.2005.13911.x

Saatkamp, A., Affre, L., Dutoit, T., Poschlod, P., 2009. The seed bank longevity index revisited: limited reliability evident from a burial experiment and database analyses. Ann Bot 104, 715-724. doi:10.1093/aob/mcp148

Schladweiler, B.K., Vance, G.F., Legg, D.E., Munn, L.C., Haroian, R., 2005. Topsoil Depth Effects on Reclaimed Coal Mine and Native Area Vegetation in Northeastern Wyoming. Rangeland Ecology \& Management 58, 167-176.

SER, Society for Ecological Restoration International, Science \& Policy Working Group, 2004. The SER International Primer on Ecological Restoration, 2nd ed. Society for Ecological Restoration International, Tucson, AZ, USA.

Sheoran, V., Sheoran, A., Poonia, P., 2010. Soil Reclamation of Abandoned Mine Land by Revegetation: A Review. International Journal of Soil, Sediment and Water 3.

Simón-Torres, M., del Moral-Torres, F., de Haro-Lozano, S., Gómez-Mercado, F., 2014. Restoration of dump deposits from quarries in a Mediterranean climate using marble industry waste. Ecological Engineering 71, 94-100. doi:10.1016/j.ecoleng.2014.07.039

Sparks, D.L., Page, A.L., Helmke, P.A., Loeppert, R.H., Soltanpour, P., Tabatabai, M.A., Johnston, C.T., Sumner, M.E., 1996. Methods of soil analysis. Part 3 - chemical methods. 1390.

Stahl, P.D., Perryman, B.L., Sharmasarkar, S., Munn, L.C., 2002. Topsoil Stockpiling Versus Exposure to Traffic: A Case Study on In situ Uranium Wellfields. Restoration Ecology 10, 129-137. doi:10.1046/j.1526-100X.2002.10114.X

Strohmayer, P., 1999. Soil Stockpiling for Reclamation and Restoration activities after Mining and Construction.

Tatin, L., Wolff, A., Boutin, J., Colliot, E., Dutoit, T., 2013. Écologie et conservation d'une steppe méditerranéenne: La plaine de Crau. Editions Quae.

Teixeira, L.H., Weisser, W., Ganade, G., 2016. Facilitation and sand burial affect plant survival during restoration of a tropical coastal sand dune degraded by tourist cars. Restor Ecol n/a-n/a. doi:10.1111/rec.12327

Thomas, G.W., 1996. Soil pH and Soil Acidity, in: Sparks, D.L., Page, A.L., Helmke, P.A., Loeppert, R.H., Soltanpour, P.N., Tabatabai, M.A., Johnston, C.T., \& Sumner, M.E., 1996. Methods of Soil Analysis Part 3 - Chemical Methods. Soil Science Society of America Book Series, pp. 475-490.

Török, P., Miglécz, T., Valkó, O., Kelemen, A., Tóth, K., Lengyel, S., Tóthmérész, B., 2012. Fast restoration of grassland vegetation by a combination of seed mixture sowing and low-diversity hay transfer. Ecological Engineering 44, 133-138. doi:10.1016/j.ecoleng.2012.03.010

UNEP, UNDP, OSCE, NATO, 2005. Mining for Closure: Policies and Guide-lines for Sustainable Mining Practice and Closure of Mines. United Nations Environment Programme (UNEP), United Nations Development Programme (UNDP), Organization for Security and Co-operation in Europe (OSCE) andNorth Atlantic Treaty Organization (NATO). Europe 97.

Vécrin, M. p., Muller, S., 2003. Top-soil translocation as a technique in the re-creation of species-rich meadows. Applied Vegetation Science 6, 271-278. doi:10.1111/j.1654-109X.2003.tb00588.x 
Wang, J., Li, Z., Hu, X., Wang, J., Wang, D., Qin, P., 2011. The ecological potential of a restored abandoned quarry ecosystem in Mt. Mufu, Nanjing, China. Ecological Engineering 37, 833-841. doi:10.1016/j.ecoleng.2010.12.026

Weber, J., Strączyńska, S., Kocowicz, A., Gilewska, M., Bogacz, A., Gwiżdż, M., Debicka, M., 2015. Properties of soil materials derived from fly ash 11 years after revegetation of post-mining excavation. CATENA 133, 250-254. doi:10.1016/j.catena.2015.05.016

Weng, L.P., Wolthoorn, A., Lexmond, T.M., Temminghoff, E.J.M., van Riemsdijk, W.H., 2004. Understanding the Effects of Soil Characteristics on Phytotoxicity and Bioavailability of Nickel Using Speciation Models. Environ. Sci. Technol. 38, 156-162. doi:10.1021/es030053r

Zeng, F., Ali, S., Zhang, H., Ouyang, Y., Qiu, B., Wu, F., Zhang, G., 2011. The influence of $\mathrm{pH}$ and organic matter content in paddy soil on heavy metal availability and their uptake by rice plants. Environ. Pollut. 159, 84-91. doi:10.1016/j.envpol.2010.09.019

Zobel, M., van der Maarel, E., Dupré, C., 1998. Species pool: the concept, its determination and significance for community restoration. Applied Vegetation Science 1, 55-66. doi:10.2307/1479085 